\title{
Wurster aza-crown ethers with $N$-para-phenylene-phenothiazine or -phenoxazine groups
}

\author{
Ana Cristina Radutiu, ${ }^{a}$ Ion Baciu, ${ }^{b}$ Miron T. Caproiu, ${ }^{c}$ Constantin Draghici, \\ Adrian Beteringhe, ${ }^{\mathrm{a}}$ Gabriela Ionita, ${ }^{\mathrm{a}}$ Petre Ionita, ${ }^{\mathrm{a}, \mathrm{b}}$ Tanta Spataru, ${ }^{\mathrm{a}}$ Nicolae Spataru, \\ Rodica D. Baratoiu, ${ }^{a}$ Titus Contantinescu, ${ }^{a}$ and Alexandru T. Balaban ${ }^{\mathrm{d} *}$ \\ a Roumanian Academy, "Ilie Murgulescu” Institute of Physical Chemistry, Splaiul Independentei \\ 202, 060021, Roumania \\ ${ }^{b}$ University of Bucharest, Department of Organic Chemistry, Soseaua Panduri 90-92, \\ Bucharest, Roumania \\ ${ }^{c}$ Roumanian Academy, “C. D. Nenitzescu” Institute of Organic Chemistry, NMR Department, \\ Splaiul Independentei 202 B, Bucharest, Roumania \\ ${ }^{d}$ Texas A\&M University at Galveston, 5007 Ave. U, Galveston, TX, 77553-1675, USA \\ E-mail: balabana@tamug.edu
}

\begin{abstract}
$N$-Phenylaza-15-crown-5 3 reacts with phenothiazine 1a, 2-chlorophenothiazine 1b, or phenoxazine 1c in the presence of mild oxidizing agents $\left(\mathrm{I}_{2}, \mathrm{Fe}^{3+}\right.$ or $\left.\mathrm{Cu}^{2+}\right)$ affording new Wurster aza-crown-ethers 4a-4c. Homolytic processes for the formation of compounds 4a-4c were discussed. Redox properties of these compounds were investigated by cyclic voltammetry. In concentrated sulfuric acid as solvent and oxidant, these compounds give stable radical-cations as proved by electron paramagnetic resonance (EPR). Ionophoric properties of the new compounds 4a-4c were evidenced by cyclic voltammetry with lithium and sodium cations. The relative hydrophobic/hydrophilic character of these compounds was determined by reverse-phase thinlayer chromatography (RP-TLC). Redox and ionophoric properties of the new compounds $\mathbf{4 a - 4 c}$ may lead to analytical and bioanalytical applications.
\end{abstract}

Keywords: Phenothiazine, phenoxazine, Wurster's crown analogs, cyclic voltammetry, spectrophotometry, EPR, RP-TLC

\section{Introduction}

"Wurster's Blue" ( $N, N, N^{\prime}, N^{\prime}$-tetramethyl-1,4-benzenediamine radical-cation) was described in 1879. ${ }^{1-3} \mathrm{~A}$ spectacular reaction is shown on the web, and takes place between a colorless solution 
of tetramethyl para-phenylenediamine on treatment with bromine gas affording a deep blue solution that becomes colorless again with an excess of bromine due to the sequential formation of the radical-cation and the dication. "Wurster's aza-crown-ethers" that have been described so far exhibit interesting chromophoric, ionophoric and redox properties, but their synthesis involves several steps. ${ }^{5-17}$

Derivatives of phenothiazine 1a and 2-chlorophenothiazine 1b have remarkable biological activities and medical applications, ${ }^{2,18}$ e. g.: Chlorproethazine, Chlorpromazine, Levomepromazine, Methophenazine, Methiazinic acid, Piperacetazine, etc. For 1a derivatives one can also mention dyestuffs ${ }^{2}$ such as Methylene Blue, Azur A, B and C. Among analogous phenoxazine 1c derivatives with various uses, ${ }^{19}$ one can mention natural antibiotics such as actinomicines, dyes such as Meldola's Blue and gallocyanine, and reagents for analytical or bioanalytical uses such as Amplex Red Reagent (10-acetyl-3,5-dihydroxy-phenoxazine), Resorufine (7-hydroxyphenoxazine-3-one- $N$-oxide) and its sodium salt as well as 6-chloro-9nitro-5-oxo-5H-benzo $[a]$ phenoxazine. ${ }^{19,20}$

Till now, no "Wurster's crowns" coupled with heterocycles 1a, 1b or 1c have been described. We present here a straightforward pathway for obtaining "Wurster's aza-crownethers" 4 , involving a simple homolytic aromatic substitution of $N$-phenylaza-15-crown-5 3 by a free radical $\mathbf{2}$ resulting from 1a, $\mathbf{1 b}$ or $\mathbf{1 c}$ (Schemes 1 and 2).

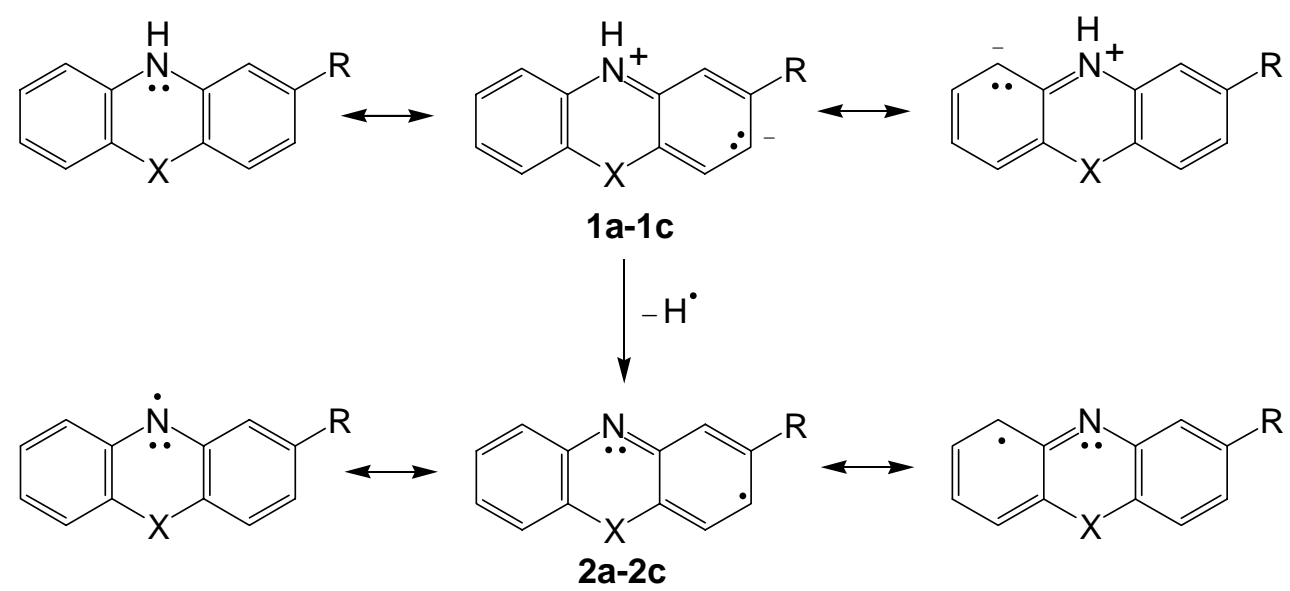

Scheme 1. A few of the resonance structures of phenothiazines $1 \mathbf{a}, \mathbf{1 b}$ and phenoxazine $\mathbf{1 c}$ and of the corresponding neutral free radicals 2a-2c: $\mathbf{a}, \mathrm{X}=\mathrm{S}, \mathrm{R}=\mathrm{H} ; \mathbf{b}, \mathrm{X}=\mathrm{S}, \mathrm{R}=\mathrm{Cl} ; \mathbf{c}, \mathrm{X}=\mathrm{O}, \mathrm{R}=\mathrm{H}$.

The yield in the "Wurster's aza-crown-ethers" $\mathbf{4 a - 4 c}$ is satisfactory (above 50\%) for this direct synthetic approach (Scheme 2). The present communication describes the synthesis and properties of these new "Wurster's aza-crown-ethers" 4, combining the ionophoric affinity for $\mathrm{Li}^{+}$and $\mathrm{Na}^{+}$with the chromophoric and redox properties of the Wurster moiety. ${ }^{8,9}$ 


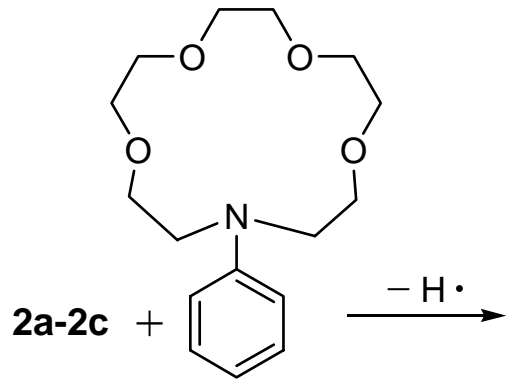

3<smiles>[R]c1ccc([X])c(N2c3ccccc3[X]c3ccccc32)c1</smiles>

Scheme 2. One-step synthesis of Wurster aza-crown-ethers 4: homolytic aromatic substitution of $\mathrm{N}$-phenylaza-15-crown-5 3 by free radicals 2a-2c (with $\mathbf{a}, \mathrm{R}=\mathrm{H}, \mathrm{X}=\mathrm{S} ; \mathbf{b}, \mathrm{R}=\mathrm{Cl}, \mathrm{X}=\mathrm{S} ; \mathbf{c}, \mathrm{R}=\mathrm{H}$, $\mathrm{X}=\mathrm{O}$ ) resulting from the oxidation of phenothiazine or phenoxazine derivatives.

\section{Results and Discussion}

\section{Synthesis of compounds $\mathbf{4 a}-\mathbf{4 c}$. Reaction conditions and mechanism}

Oxidation of the three heterocycles ${ }^{3,18,19} \mathbf{1 a - 1 c}$ converts them into free radicals $\mathbf{2 a - 2 c}$, as seen in Scheme 1, which dimerize rapidly to 5 and $\mathbf{6}^{18,19,21,22}$ (with an N-C bond).<smiles></smiles>

$5 a-5 c$<smiles></smiles>

6a-6c

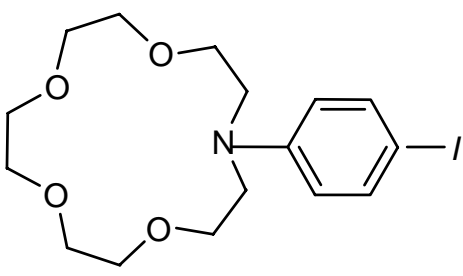

7

a, $\mathrm{X}=\mathrm{S}, \mathrm{R}=\mathrm{H} ; \mathbf{b}, \mathrm{X}=\mathrm{S}, \mathrm{R}=\mathrm{Cl} ; \mathbf{c}, \mathrm{X}=\mathrm{O}, \mathrm{R}=\mathrm{H}$.

Some oxidative reactions of phenothiazine 1a and phenoxazine 1c involve heterolytic reactions in the presence of nucleophiles and afford colored products with quinonoid structures (by substitution of the heterocyclic ring), which can be reduced to the corresponding leucoderivatives. $^{23-25}$ In the present case, however, the reaction mechanism in methanol at room 
temperature in the presence of mild oxidizing agents $\left(\mathrm{I}_{2}, \mathrm{Fe}^{3+}\right.$ or $\left.\mathrm{Cu}^{2+}\right)$ is a homolytic aromatic substitution, involving the $N$-phenylaza-15-crown-5 3 and the nitrogen atom of the free radicals 2a-2c (Scheme 1), affording compounds 4a-4c (Scheme 2). This statement is based on the following experimental observations:

i. as seen in Table 1 for the first oxidation step, compounds 1a-1c are oxidized more easily than N-phenylaza-15-crown-5 3;

ii. irrespective of the oxidizing agent $\left(\mathrm{I}_{2}, \mathrm{Fe}^{3+}\right.$ or $\left.\mathrm{Cu}^{2+}\right)$, the dimers $5 \mathbf{a}, 5 \mathbf{c}$ and $\mathbf{6 a}, \mathbf{6 c}$ (evidenced by TLC, along with other side-products), proved the formation of the neutral free radicals $\mathbf{2 a}-\mathbf{2 c}$;

iii. since the literature mentions that dimers 5a and $\mathbf{6 a}$ are formed from phenothiazine 1a and the stable free radical DPPH (2,2-diphenyl-1-picrylhydrazyl) or solid $\mathrm{PbO}_{2},{ }^{3,26,27}$ we investigated the reaction between $1 \mathbf{a}$ and $\mathbf{3}$ in methylene chloride and each of these two oxidizing agents at room temperature for $24 \mathrm{hrs}$; along with dimers 5a and 6a in significant amounts, TLC showed the presence of $\mathbf{4 a}$ in low concentration;

iv. on monitoring by cyclic voltammetry the reaction of 1a with $\mathbf{3}$ in acetonitrile, one reversible major peak was detected (Figure 1), and TLC of the oxidation products evidenced the electrochemical formation of 1a, 3, 4a and dimers 5a and $\mathbf{6 a}$ in the absence of chemical oxidants (see Experimental Part);

v. no reaction occurs when phenothiazine 1a is replaced by N-methylphenothiazine; this experiment proves that the $\mathrm{N}$-centered stable free radical $\mathbf{2 a}$ is essential for the formation of 4a;

vi. sodium acetate, which favors heterolytic processes, ${ }^{24}$ lowers the yield in products $\mathbf{4 a}$ or $\mathbf{4 c}$, as one can see in Table 2 (the ratios between the aromatic heterocycle, 1a or 1c, Nphenylaza-15-crown-5 3 and oxidizing agent are also displayed in Table 2).

Table 1. Peak potentials (V vs. $\mathrm{Ag} / \mathrm{Ag}^{+}$) for oxidation (EpaI and EpaII) and reduction (EpcI and EpcII) of compounds 1a-1c and $3\left(10^{-3} \mathrm{M}\right)$ in acetonitrile in the presence of tetra-nbutylammonium perchlorate, TBAP $\left(10^{-1} \mathrm{M}\right)$

\begin{tabular}{ccccc}
\hline Compound & EpaI & EpcI & EpaII & EpcII \\
\hline $\mathbf{1 a}$ & 0.30 & 0.18 & 0.71 & - \\
$\mathbf{1 b}$ & 0.41 & 0.31 & 0.71 & - \\
$\mathbf{1 c}$ & 0.36 & 0.22 & 0.85 & - \\
$\mathbf{3}$ & 0.50 & - & - & - \\
\hline
\end{tabular}




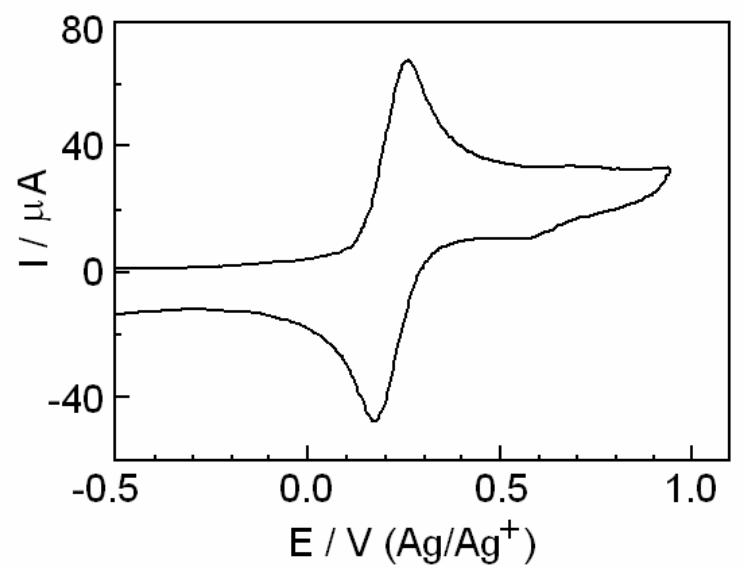

Figure 1. Cyclic voltammogram recorded for a mixture of $\mathbf{1 a}$ and $\mathbf{3}$ in acetonitrile with TBAP $\left(10^{-1} \mathrm{M}\right)$ as supporting electrolyte in concentrations of $10^{-3} \mathrm{M}$, at a scan rate of $0.5 \mathrm{~V} / \mathrm{s}$; Epa $=0.27$ $\mathrm{V}$ and $\mathrm{Epc}=0.16 \mathrm{~V}$.

Table 2. Yields of compounds $4 \mathbf{a}, \mathbf{4} \mathbf{c}$ as a function of experimental conditions ${ }^{\mathrm{a}}$

\begin{tabular}{|c|c|c|c|}
\hline \multirow{2}{*}{ Reactants (molar ratio) } & \multirow{2}{*}{$\begin{array}{c}\mathrm{CH}_{3} \mathrm{COONa}(\text { moles } \\
\text { relative to 1a, 1c) }\end{array}$} & \multicolumn{2}{|c|}{$\%^{\mathrm{b}}$ relative to $1 \mathrm{a}, \mathbf{1 c}$} \\
\hline & & $4 a$ & $4 c$ \\
\hline $\mathbf{1 a}+3+\mathrm{I}_{2}(1: 1: 1)$ & & 29 & \\
\hline $\mathbf{1} \mathbf{a}+\mathbf{3}+\mathrm{I}_{2}(1: 1: 1.5)$ & & 52 & \\
\hline $\mathbf{1} \mathbf{a}+\mathbf{3}+\mathrm{I}_{2}(1: 1: 2.2)$ & & 48 & \\
\hline $\mathbf{1 a}+\mathbf{3}+\mathrm{I}_{2}(1: 1: 1)$ & 2.2 & 17 & \\
\hline $\mathbf{1} \mathbf{a}+3+I_{2}(1: 1: 1.5)$ & 2.2 & 33 & \\
\hline $\mathbf{1 a}+3+I_{2}(1: 1: 2.2)$ & 2.2 & 25 & \\
\hline $\mathbf{1 a}+\mathbf{3}+\mathrm{FeCl}_{3}$ anh. $(1: 1: 1.5)$ & & 31 & \\
\hline $\mathbf{1} \mathbf{a}+\mathbf{3}+\mathrm{FeCl}_{3}$ anh. $(1: 1: 1.5)$ & 2.2 & 26 & \\
\hline $\mathbf{1 a}+3+\mathrm{FeCl}_{3} \cdot 6 \mathrm{H}_{2} \mathrm{O}(1: 1: 1.5)$ & & 24 & \\
\hline $\mathbf{1 a}+3+\mathrm{FeCl}_{3} \cdot 6 \mathrm{H}_{2} \mathrm{O}(1: 1: 1.5)$ & 2.2 & 22 & \\
\hline $\mathbf{1 a}+3+\mathrm{CuCl}_{2} .2 \mathrm{H}_{2} \mathrm{O}(1: 1: 1.5)$ & & 50 & \\
\hline $\mathbf{1} \mathbf{a}+3+\mathrm{CuCl}_{2} .2 \mathrm{H}_{2} \mathrm{O}(1: 1: 1.5)$ & 2.2 & 32 & \\
\hline $\mathbf{1 c}+3+\mathrm{I}_{2}(1: 1: 1.5)$ & & & 51 \\
\hline $\mathbf{1 c}+3+\mathrm{I}_{2}(1: 1: 1.5)$ & 2.2 & & 23 \\
\hline $\mathbf{1 c}+\mathbf{3}+\mathrm{FeCl}_{3}$ anh. $(1: 1: 1.5)$ & & & 30 \\
\hline $\mathbf{1 c}+\mathbf{3}+\mathrm{FeCl}_{3}$ anh. $(1: 1: 1.5)$ & 2.2 & & 10 \\
\hline
\end{tabular}

${ }^{a}$ solvent methanol at room temperature for $24 \mathrm{hrs}$ under stirring;

${ }^{\mathrm{b}}$ after work-up and isolation by TLC (see Experimental Part). 
When iodine was used as an oxidizing agent for the reaction between 1a-1c and 3, another product (7 in $10-15 \%$ yield relatively to 3 ) was identified, in addition to $\mathbf{4 a - 4 c}, \mathbf{5 a}-\mathbf{5 c}$, and $\mathbf{6 a -}$ 6c. The iodo-derivative $\mathbf{7}$ has been described in the literature as the reaction product between $\mathbf{3}$ and $N$-iodosuccinimide, involving probably also a homolytic process. ${ }^{28} \mathrm{We}$ have obtained it as the main reaction product from 3 and iodine in methanol (74\% yield, see Experimental Part).

An excess of oxidizing agent (iodine) up to $50 \%$ increases the yield in compounds 4 but a larger excess lowers it (the first six experiments in Table 2), so that the other experiments were carried out with equimolar amounts of reactants 1a, 1c and $\mathbf{3}$, and with 1.5 moles of oxidant per mole of each reactant (Table 2).

When iodine was used as oxidant, about half of the unreacted crown ether 3 could be recovered $(20 \%)$.

The reaction involving 2-chlorophenothiazine $\mathbf{1 b}$ with molar ratios $\mathbf{1 b}: 3: \mathrm{I}_{2}=1: 1: 1.5$ yielded the product $\mathbf{4} \mathbf{b}$ in $53 \%$ yield, indicating that substituted derivatives of these aromatic heterocycles can also be used satisfactorily.

In the presence of water (or hydrated oxidizing agents, Table 2) one obtains from 1a or 1c, along with other side-products, phenothiazin-3-one or phenoxazin-3-one (these products may also be observed when the first step of the work-up involves aqueous solutions ${ }^{18,19}$ ).

Owing to the basicity of the tertiary aminic groups, compounds $\mathbf{4 a}-\mathbf{4 c}$ can be protonated to 4Ha-4Hc in acidic media (Scheme 3). The initial mixture of the two reactants $N$-phenylaza-15crown-5 (3) and the aromatic heterocycle 1a-1c in methanol is yellow, but on adding an excess of oxidizing agent the mixture becomes deeply colored. Compounds $4 \mathbf{a}-4 \mathbf{c}$ can be oxidized to cation-radicals 8a-8c ("Wurster's aza-crown-ethers") and dications 9a-9c, similarly to "Wurster's Blue" cation-radical $\left(N, N, N^{\prime}, N\right.$ '-tetramethyl-1,4-benzenediamine radical-cation ${ }^{4,18,19}$ ), see the Redox reactions paragraph. In acid and oxidative medium, dication-radicals 8Ha-8Hc and dications 9a-9c may also be formed (Scheme 3), see EPR spectra paragraph. On adding reducing agents to this reaction mixture (ascorbic acid for $\mathrm{Fe}^{3+}$ or $\mathrm{Cu}^{2+}$, or ascorbic acid and sodium thiosulfate for $\mathrm{I}_{2}$ ), the color returns gradually to yellow, reforming compounds $\mathbf{4 a - 4 c}$ (see Experimental Part).

Two less likely alternatives to the homolytic aromatic substitution mechanism presented in Scheme 2 are: (i) a coupling of two radicals formed by oxidation of both reactants $\mathbf{1}$ and $\mathbf{3}$ (as seen from Table 1, whereas 1a-1c have oxidation potentials of $0.3-0.4 \mathrm{~V}$, the macrocyclic amine 3 has a higher oxidation potential, $0.5 \mathrm{~V}$ ); (ii) a homolytic ipso-substitution ${ }^{29}$ for the case when iodine was the oxidizing agent, involving the formation of the iodo-derivative 7 that would react with radical 2a-2c displacing the iodine; actually, on reacting in methanol for $24 \mathrm{hrs}$. at room temperature an equimolar mixture of $\mathbf{1 a}$ and $\mathbf{7}$ with an excess of anhydrous $\mathrm{FeCl}_{3}$ and then extracting the mixture with methylene chloride and analyzing the products by TLC, 4a was detected in $40 \%$ yield. 


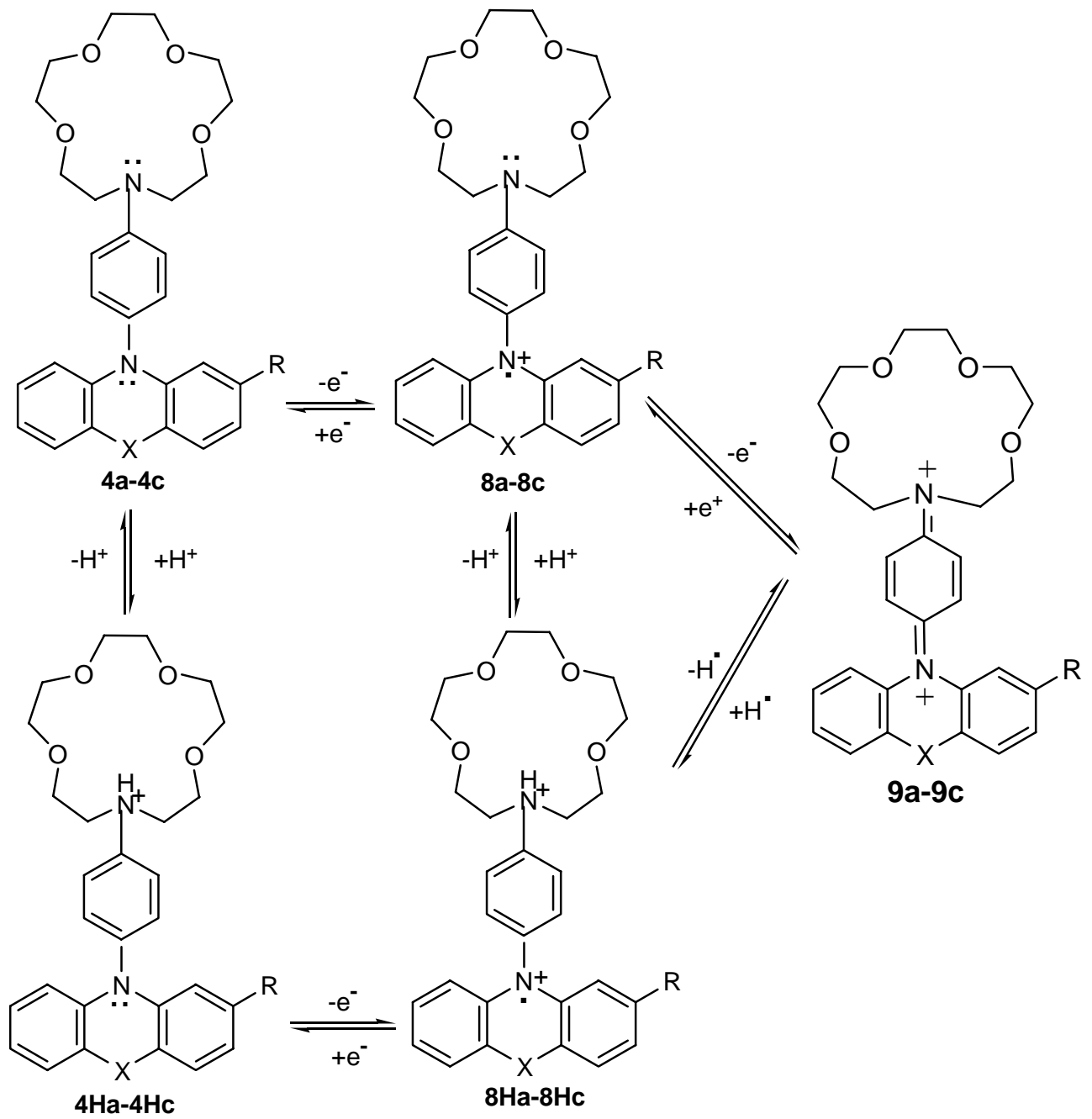

a, $\mathrm{X}=\mathrm{S}, \mathrm{R}=\mathrm{H} ; \mathbf{b}, \mathrm{X}=\mathrm{S}, \mathrm{R}=\mathrm{Cl} ; \mathbf{c}, \mathrm{X}=\mathrm{O}, \mathrm{R}=\mathrm{H}$.

Scheme 3. Reversible processes converting compounds $\mathbf{4 a - 4 c}$ into conjugate acids $\mathbf{4 H a}-\mathbf{4 H c}$, and redox processes affording radical-cations $8 \mathbf{8}-\mathbf{8 c}$ or their conjugate acids $\mathbf{8 H a}-\mathbf{4 8 c}$, and dications 9a-9c.

\section{NMR and IR Spectra of the new Wurster aza-crown-ethers 4a-4c}

Both by ${ }^{1} \mathrm{H}-\mathrm{NMR}$ and ${ }^{13} \mathrm{C}-\mathrm{NMR}$ spectra (see Experimental Part), the structures of the new compounds $4 \mathbf{a}-\mathbf{4 c}$ were confirmed. The following remarks should be noted:

i. the symmetry of the unsubstituted heterocycle $\mathbf{4 a}$ and $\mathbf{4} \mathbf{c}$ is reflected by the pairwise equality of $\delta$ values for H-1-9, H-2-8, H-3-7, H-4-6 and for C-1-9, C-2-8, C-3-7, C-4-6; however, this symmetry is broken by the 2-chloro-substituent in $\mathbf{4 b}$;

ii. ${ }^{1} \mathrm{H}$ - and ${ }^{13} \mathrm{C}-\mathrm{NMR}$ chemical shift $\delta$ values for positions 4 and 6 decrease on replacing the sulfur heteroatom by the more electronegative oxygen heteroatom $\mathbf{4 a}>\mathbf{4 c}$;

iii. for compound 7, NMR data are similar to those reported in the literature ${ }^{28}$ and confirm the para-position of the iodo substituent in N-phenylaza-15-crown-5, 3. 
Infrared absorption spectra of compounds $\mathbf{4 a}-\mathbf{4 c}$ confirm the absence of the NH stretching frequency in these products.

\section{Redox reactions of the new Wurster aza-crown-ethers 4a-4c}

Cyclic voltammetry of compounds $\mathbf{4 a - 4 c}$ using tetra-n-butylammonium perchlorate (TBAP) as supporting electrolyte evidenced two redox reactions (peaks I and II) in reversible processes (Figure 2), corresponding to Scheme 3, similarly to other Wurster compounds., ${ }^{3,5-9}$

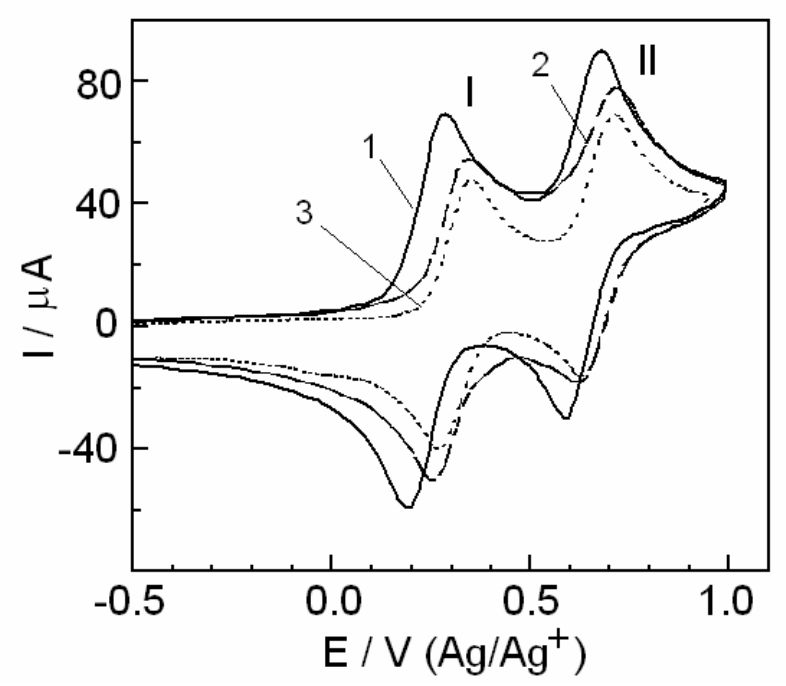

Figure 2. Cyclic voltammograms recorded for a concentration of $10^{-3} \mathrm{M}$ in acetonitrile of compounds 4a (full line, 1), $\mathbf{4 b}$ (dotted line, 3) and 4c (dashed line, 2); scan rate $0.5 \mathrm{~V} \mathrm{~s}^{-1}$, supporting electrolyte TBAP $\left(10^{-1} \mathrm{M}\right)$.

The oxidation potentials (Figure 2) increase in the order $\mathbf{4 a}<\mathbf{4 b} \approx \mathbf{4} \mathbf{c}$, for each of the oxidation steps (Table 3).

Table 3. Peak potentials (V vs. $\mathrm{Ag} / \mathrm{Ag}^{+}$) for oxidation (EpaI and EpaII) and reduction (EpcI and EpcII) of compounds $4 \mathbf{a}-\mathbf{4 c}\left(10^{-3} \mathrm{M}\right)$ in acetonitrile in the presence of tetra-n-butylammonium perchlorate, TBAP $\left(10^{-1} \mathrm{M}\right)$

\begin{tabular}{ccccc}
\hline Compound & EpaI & EpcI & EpaII & EpcII \\
\hline $\mathbf{4 a}$ & 0.25 & 0.18 & 0.68 & 0.60 \\
$\mathbf{4 b}$ & 0.36 & 0.27 & 0.72 & 0.64 \\
$\mathbf{4 c}$ & 0.35 & 0.25 & 0.72 & 0.62 \\
\hline
\end{tabular}

When $\mathrm{LiClO}_{4}$ or $\mathrm{NaClO}_{4}$ are used as a support electrolyte, the voltammograms indicated also a reversible system (Figure 3). 


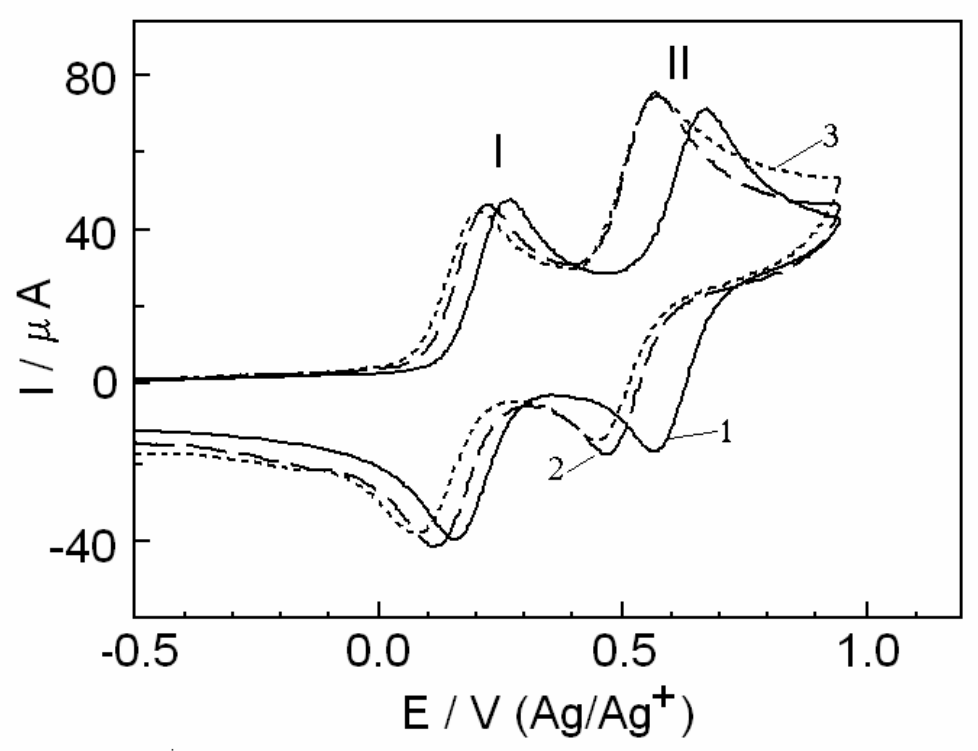

Figure 3. Characteristic voltammetric patterns for $4 \mathbf{a}\left(10^{-3} \mathrm{M}\right.$ in acetonitrile) in the presence of different supporting electrolytes: TMAP (full line, 1), $\mathrm{NaClO}_{4}$ (dashed line, 2), $\mathrm{LiClO}_{4}$ (dotted line, 3); concentration of the supporting electrolyte is $10^{-1} \mathrm{M}$; scan rate $0.5 \mathrm{~V} \mathrm{~s}^{-1}$.

With tetramethylammonium perchlorate (TMAP) as reference, Table 4 indicates that the oxidation potentials decrease with these cations $\left(\mathrm{Li}^{+}\right.$or $\left.\mathrm{Na}^{+}\right)$. This fact proves that the lone electron pair of the nitrogen atom in the macrocycle becomes involved in the complex formation.

Table 4. Oxidation (EpaI and EpaII) and reduction (EpcI and EpcII) peak potentials (V vs. $\left.\mathrm{Ag} / \mathrm{Ag}^{+}\right)$of $4 \mathbf{a}$ in acetonitrile $\left(10^{-3} \mathrm{M}\right)$ in the presence of various supporting electrolytes $\left(10^{-1} \mathrm{M}\right)$

\begin{tabular}{ccccc}
\hline Electrolyte & EpaI & EpcI & EpaII & EpcII \\
\hline TMAP & 0.26 & 0.17 & 0.68 & 0.60 \\
$\mathrm{NaClO}_{4}$ & 0.23 & 0.11 & 0.58 & 0.47 \\
$\mathrm{LiClO}_{4}$ & 0.22 & 0.08 & 0.58 & 0.44 \\
\hline
\end{tabular}

Cyclic voltammograms (Figure 3) and peak potentials (Table 4) demonstrated that the resulting supramolecular assembly $\left(\mathbf{4 a}-\mathrm{M}^{+}\right.$complex) is stable, and so is also its mono-oxidation product $\left(\mathbf{8 a}-\mathrm{M}^{+}\right.$complex); however, the next oxidation step no longer has a lone electron pair at the macrocyclic nitrogen atom, and therefore this is no longer stable, ${ }^{8,9}$ but forms the dication $9 \mathbf{a}$ releasing the alkaline metal cation (Scheme 4). 

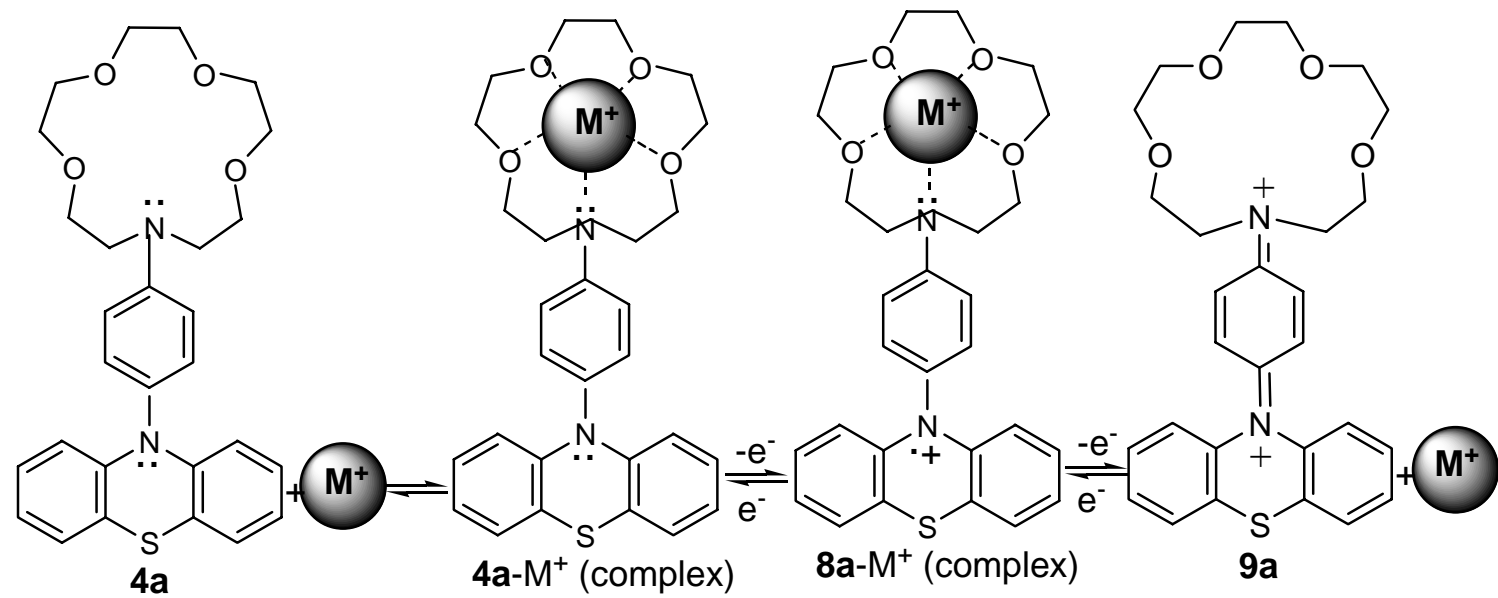

Scheme 4. Reversible redox ionophoric process of $4 \mathrm{a}$ in the presence of alkali metal ions $\left(\mathrm{M}^{+}=\mathrm{Li}\right.$ or $\mathrm{Na}$ )

The complexation of $\mathrm{Li}^{+}$or $\mathrm{Na}^{+}$with 4a (Table 4) is in agreement with data reported in the literature, ${ }^{30}$ regarding the fitting between the ionic diameter and the macrocyclic cavity size (1.2$1.5 \AA$ ) of the $N$-phenylaza-15-crown-5 3 and the ionic diameters for $\mathrm{Li}^{+}(1.36 \AA)$ and $\mathrm{Na}^{+}(1.94$ $\AA)$ respectively. In the case of $\mathrm{K}^{+}$with larger ionic diameter $(2.66 \AA),{ }^{30}$ our investigations revealed no complex formation.

\section{Spectrophotometry of the new Wurster aza-crown-ethers 4a-4c}

The electronic absorption spectra in the $230-325 \mathrm{~nm}$ range of methanol solutions of $\mathbf{1 a}-\mathbf{1 c}, \mathbf{3}$ and 4a-4c are displayed in Table 5. The following observations hold:

i. all seven compounds present two distinct absorption maxima at 238-259 $\mathrm{nm}$ and 302-323 $\mathrm{nm}$. In addition, compounds $\mathbf{4 a}-\mathbf{4 c}$ have a third band at $265 \mathrm{~nm}$ appearing as a shoulder for 4a and $\mathbf{4 b}$ (on the $257 \mathrm{~nm}$ or $259 \mathrm{~nm}$ absorption band, respectively), but as distinct maximum for $\mathbf{4 c}$;

ii. taking into account that compounds $\mathbf{4 a - 4 c}$ possess both molecular moieties of $\mathbf{1 a}-\mathbf{1 c}$ and $\mathbf{3}$, one expects the presence of electronic transitions characterizing these moieties, and in addition a band that would be similar to that of para-phenylenediamine;

iii. in solution and as TLC spots, compounds 1a-1c and the new Wurster aza-crown-ethers 4a4c are weakly fluorescent at $366 \mathrm{~nm}$; at present, this property was not investigated more closely. 
Table 5. Spectrophotometric behavior of compounds 1, 3 and 4 in methanol

\begin{tabular}{cccc}
\hline Compounds & $\lambda_{1 \max }(\mathrm{nm})(\log \varepsilon)$ & $\lambda_{2 \max }(\mathrm{nm})(\log \varepsilon)$ & $\lambda_{3 \max }(\mathrm{nm})(\log \varepsilon)$ \\
\hline $\mathbf{1 a}^{\mathrm{a}}$ & $252(4.515)$ & & $318(3.620)$ \\
$\mathbf{1 b}^{\mathrm{b}}$ & $256(5.023)$ & & $323(4.025)$ \\
$\mathbf{1 c}^{\mathrm{b}}$ & $238(5.282)$ & & $317(4.593)$ \\
$\mathbf{3}^{\mathrm{b}}$ & $257(5.174)$ & $265(\mathrm{sh})$ & $302(4.330)$ \\
$\mathbf{4 a}^{\mathrm{c}}$ & $257(4.651)$ & $265(\mathrm{sh})$ & $312(3.716)$ \\
$\mathbf{4 b}^{\mathrm{b}}$ & $259(5.083)$ & $265(4.206)$ & $313(4.082)$ \\
$\mathbf{4 c}^{\mathrm{b}}$ & $239(4.733)$ & & $322(4.012)$ \\
\hline
\end{tabular}

${ }^{\mathrm{a}}$ concentration $10^{-4} \mathrm{M} ;{ }^{\mathrm{b}}$ concentration $10^{-5} \mathrm{M} ;{ }^{\mathrm{c}}$ concentration $5 \times 10^{-5} \mathrm{M}$.

\section{EPR Spectra of radicals formed from the new Wurster aza-crown-ethers 4a-4c}

In concentrated sulfuric acid as solvent and oxidant, compounds $\mathbf{4 a - 4 c}$ give stable radicals, but the resolution of the EPR spectra is low due to high viscosity of the solvent (Figure 4). We assume that under these conditions, in agreement with Scheme 3, radicals 8Ha-8Hc become protonated affording radical-dications $\mathbf{8 H a - 8 H c}$.

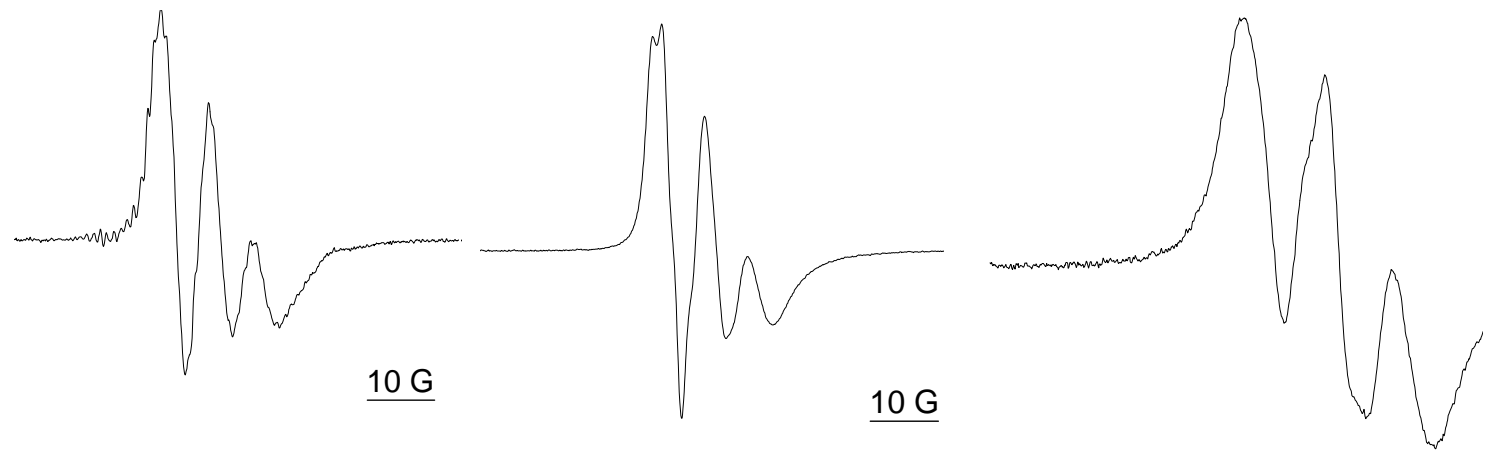

8Ha (experimental)

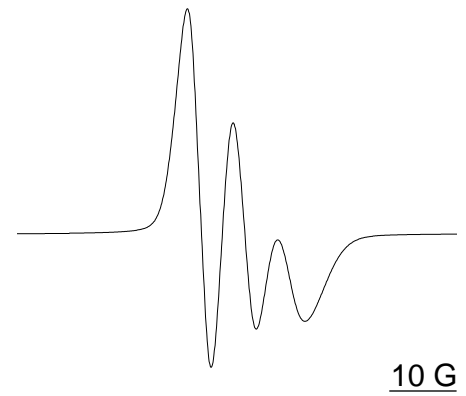

8Ha (simulated) $\mathbf{8 H b}$ (experimental)

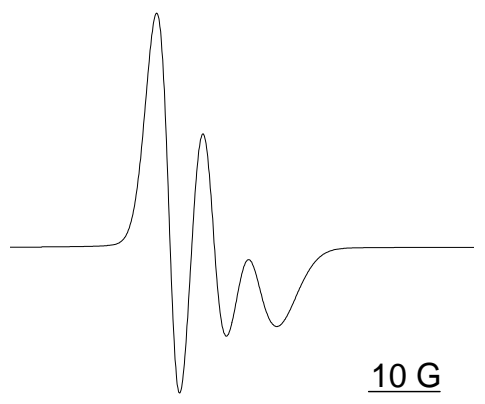

8Hb (simulated)
8Hc (experimental)

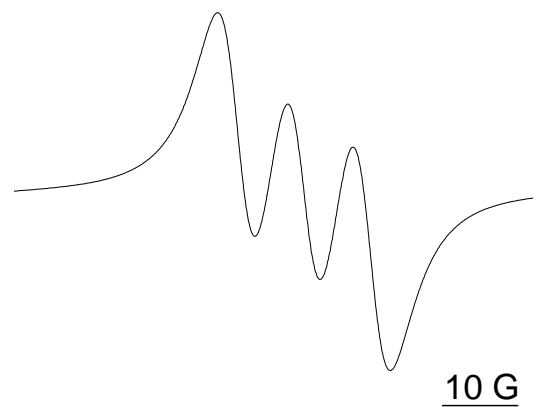

Figure 4. EPR spectra of stable radical-dications $\mathbf{8 H a - 8 H c}$, in sulfuric acid. 
The experimental $a_{N}$ values for radical-dications 8Ha-8Hc and literature $a_{N H}$ values for radical-cations 10a-10c corresponding to compounds 1a and 1c (by oxidation in acid medium ${ }^{3,18,31-37}$ or in molten salts ${ }^{32}$ ) are presented in Table 6 and its footnotes.

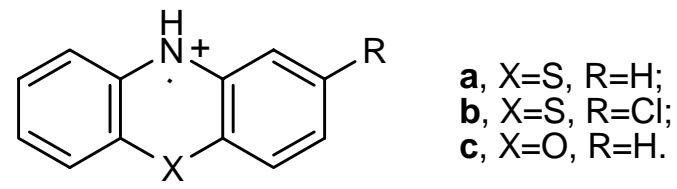

10a-10c

We can assume that the EPR spectra, $\lambda_{\max }$ and color of the new radical-dications $\mathbf{8 H a - 8 H c}$ should be comparable to those of the radical-cations 10a-10 $\mathbf{c}^{3,18,31-37}$ (Table 6).

Table 6. EPR $a_{N}$ (or $a_{N H}$ ) and $g$ values, as well as electronic absorption data for radical-dications 8Ha-8Hc (experimental values) and radical-cations 10a-10c (experimental and/or literature data values)

\begin{tabular}{cccccc}
\hline Radicals & $g$ & $a_{N}$ (gauss) & $a_{N H}$ (gauss) & $\lambda_{\max }(\mathrm{nm})$ & Color $^{\mathrm{b}}$ \\
\hline $\mathbf{8 H a}$ & 2.0076 & 6.66 & & $520^{\mathrm{b}}$ & Orange-red \\
$\mathbf{8 H b}$ & 2.0082 & 6.36 & & $534^{\mathrm{b}}$ & Red \\
$\mathbf{8 H c}$ & 2.0057 & 8.90 & & $540^{\mathrm{b}}$ & Red-violet \\
& & $6.52^{33}$ & $7.07^{\mathrm{a}}$ & & \\
10a & $2.0050^{33}$ & $6.41^{33}$ & $6.52^{3,18,31}$ & $519^{\mathrm{b}}$ & \\
& & $6.50^{33}$ & $7.10^{32}$ & $515^{32,34}$ & Orange-red \\
10b & & & $7.5^{32,33,36}$ & & \\
& & & $7.10^{\mathrm{a}}$ & $529^{\mathrm{b}}$ & Red \\
10c & $2.0049^{33}$ & $7.90^{33}$ & $9.23^{\mathrm{a}}$ & $530^{\mathrm{b}}$ & \\
& & $7.83^{33}$ & $9.83^{33}$ & $529^{32,35}$ & Red-violet \\
\hline
\end{tabular}

${ }^{a}$ our experimental values in concentrated sulfuric acid.

${ }^{b}$ the color in a mixture of benzene-acetone $(1: 1 \mathrm{v} / \mathrm{v})$ with five drops of concentrated $\mathrm{H}_{2} \mathrm{SO}_{4}$.

The red solutions of $\mathbf{4 a}-\mathbf{4} \mathbf{c}$ in concentrated sulfuric acid presenting the EPR spectra shown in Figure 4 reform these compounds on diluting with a 20-times larger amount of water. The workup was extraction with dichloromethane, drying of the colorless organic layer, and evaporating the solvent in vacuum. The pink-colored aqueous phase was neutralized with $\mathrm{NaHCO}_{3}$, and then the same procedure was followed. Analysis of both residues by TLC revealed only the presence of compounds $\mathbf{4 a - 4 c}$, proving that no degradation takes place in $\mathrm{H}_{2} \mathrm{SO}_{4}$ and that radicals $\mathbf{8 H a}$ 8Hc have no structural modifications. 


\section{Hydrophobicity/hydrophilicity balance of the new Wurster aza-crown-ethers 4a-4c}

The hydrophobicity/hydrophilicity property of compounds 4 is important for their possible chemical and biomedical applications. The octanol-water partition coefficient $(P)$ and its $\operatorname{logarithm}(\log P)$ are the usual parameters ${ }^{38}$ for estimating quantitatively these characteristics, and they can be measured or computed. In our case, this property for compounds $\mathbf{4 a - 4 c}$ was studied experimentally by reversed phase TLC $^{39-43}$ (RP-TLC) and compared with this property for the starting compounds $\mathbf{1 a - 1 c}, \mathbf{3}$, and the side-reaction compound $\mathbf{7}$. Thus, $R_{f}$ values were measured using precoated $\mathrm{C}_{18}$-chain layers (RP-18F $254 \mathrm{~S}$, Merck), as stationary phases and different acetonitrile-water mixtures as mobile phases (Table 7). The molecular hydrophobicity, $R_{M 0}$, appreciated as a result of experimental data depending on $R_{M 0}$ values and calculated ${ }^{39-43}$ with eqs. 1 and 2, is the $R_{M}$ value extrapolated to zero concentration of the organic component in the acetonitrile-water mixture; $b$ is the change in the $R_{M}$ value caused by increasing the concentration $(K)$ of the organic component in the mobile phase. Statistical analysis involved the correlation coefficient $(R)$, the Fisher parameter $(F)$, and the standard deviation $(S D)$ (Table 7).

$$
\begin{array}{ll}
R_{M}=\log \left(1 / R_{f}-1\right) & \text { eq. } 1 \\
R_{M}=R_{M 0}+b K & \text { eq. } 2
\end{array}
$$

Table 7. $R_{f}$ values, hydrophobic characteristics $\left(R_{M 0}\right.$ and $\left.b\right)$ and calculated $\log P$ of the new compounds 4 , of the starting compounds 1,3 and of the secondary reaction product 7 . RP-TLC

\begin{tabular}{|c|c|c|c|c|c|c|c|c|c|c|c|}
\hline \multirow[t]{2}{*}{ No. } & \multicolumn{5}{|c|}{$R_{f}$} & \multicolumn{2}{|c|}{$\begin{array}{l}\text { Hydrophobicity } \\
\text { characteristics }\end{array}$} & \multicolumn{3}{|c|}{ Statistical parameters } & \multirow{2}{*}{$\begin{array}{l}\log P \\
\text { calc. }\end{array}$} \\
\hline & A & $\mathrm{B}$ & $\mathrm{C}$ & $\mathrm{D}$ & $\mathrm{E}$ & $R_{M 0}$ & $b$ & $R$ & $F$ & $S D$ & \\
\hline $1 \mathbf{a}$ & 0.789 & 0.717 & 0.650 & 0.584 & 0.487 & 2.190 & -0.029 & -0.998 & 902.1 & 0.015 & 4.150 \\
\hline $1 \mathbf{b}$ & 0.679 & 0.615 & 0.513 & 0.410 & 0.346 & 2.639 & -0.031 & -0.997 & 505.8 & 0.022 & 5.180 \\
\hline 1c & 0.831 & 0.769 & 0.669 & 0.641 & 0.512 & 2.379 & -0.032 & -0.988 & 129.1 & 0.044 & 3.840 \\
\hline 3 & 0.743 & 0.692 & 0.675 & 0.623 & 0.602 & 0.879 & -0.013 & -0.984 & 95.8 & 0.022 & 0.950 \\
\hline $4 a$ & 0.428 & 0.333 & 0.289 & 0.205 & 0.161 & 2.925 & -0.029 & -0.995 & 323.1 & 0.025 & 4.830 \\
\hline $4 b$ & 0.342 & 0.220 & 0.189 & 0.129 & 0.103 & 3.336 & -0.031 & -0.986 & 106.7 & 0.048 & 5.420 \\
\hline $4 c$ & 0.460 & 0.350 & 0.297 & 0.246 & 0.168 & 2.866 & -0.029 & -0.991 & 177.5 & 0.034 & 4.430 \\
\hline 7 & 0.717 & 0.679 & 0.644 & 0.615 & 0.597 & 0.731 & -0.011 & -0.988 & 127.0 & 0.016 & 2.350 \\
\hline
\end{tabular}
results $^{\mathrm{a}, \mathrm{b}}$ for acetonitrile-water mixtures $(\mathrm{A}-\mathrm{E})$

${ }^{\mathrm{a}}$ Five determinations on silica gel $\mathrm{RP}-18 \mathrm{~F}_{254 \mathrm{~S}}$ (Merck), with percent of acetonitrile in mixture acetonitrile-water: $\mathrm{A}=95 \%, \mathrm{~B}=90 \%, \mathrm{C}=85 \%, \mathrm{D}=80 \%$ and $\mathrm{E}=75 \% ;{ }^{\mathrm{b}} R_{M 0}, b, R, F$, and $S D$ are defined by the preceding text and by eqs. 1 and 2 . 
On attempting to calculate $\log P$ values using fragmental constants, ${ }^{44}$ a satisfactory correlation with experimental data for $R_{M 0}$ was obtained (Figure 5).

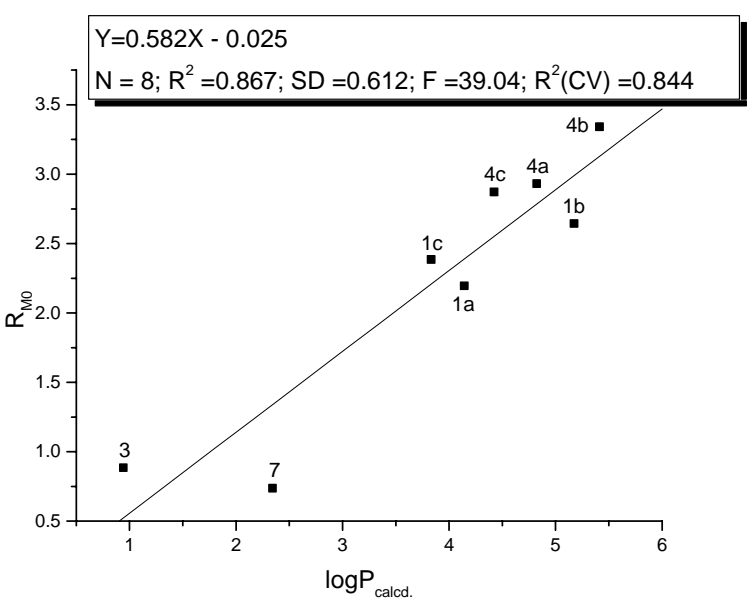

Figure 5. $\mathrm{R}_{\mathrm{M} 0}$ vs $\log P_{\text {calcd }}$ for compounds $\mathbf{1 a - 1 c}, \mathbf{3}, \mathbf{4 a - 4 c}$ and 7.

The experimental results concerning the hydrophobic/hydrophilic character $\left(R_{M 0}\right.$ values, Table 7) indicate that the starting heterocycles 1a-1c have a higher hydrophobicity than the compounds 3 and 7 containing the $N$-phenylaza-15 crown-5, and that the new Wurster azacrown-ethers $\mathbf{4 a}-\mathbf{4 c}$ are the most hydrophobic of all.

\section{Conclusions}

In a one-step synthesis, the free radicals $\mathbf{2 a - 2 c}$ obtained by oxidizing (with $\mathrm{I}_{2}, \mathrm{Fe}^{3+}$ or $\mathrm{Cu}^{2+}$ ) phenothiazine 1a, 2-chlorophenothiazine 1b, or phenoxazine 1c afford by homolytic aromatic substitution of $N$-phenylaza-15-crown-5 3 new "Wurster's aza-crown-ethers" 4a-4c. The structures were confirmed by mass spectrometry, ${ }^{1} \mathrm{H}-\mathrm{NMR}$ and ${ }^{13} \mathrm{C}-\mathrm{NMR}$ spectra. Redox reactions yielding the Wurster radical-cations 8a-8c and the corresponding dications 9a-9c were explored by cyclic voltammetry. In the presence of lithium and sodium cations, oxidation potentials of 4a decrease, proving the ionophoric character of this new "Wurster's aza-crownether". In concentrated sulfuric acid stable radical-dications 8Ha-8Hc are formed, as proved by EPR spectra. The hydrophobicity of the new "Wurster's aza-crown-ethers" 4a-4c was determined experimentally by RP-TLC. Compounds 4a-4c may lead to analytical and bioanalytical applications. 


\section{Experimental Section}

General. Phenothiazine 1a, 2-chlorophenothiazine 1b, phenoxazine 1c, N-methylphenothiazine, iodine, ascorbic acid, $\mathrm{CuCl}_{2} \cdot 2 \mathrm{H}_{2} \mathrm{O}$, anhydrous sodium acetate, sodium thiosulfate, anhydrous sodium sulfate, and lead dioxide were from Aldrich; N-phenylaza-15-crown-5 3, anhydrous $\mathrm{FeCl}_{3}, \mathrm{NaClO}_{4} \cdot \mathrm{H}_{2} \mathrm{O}$, PLC plates Silica Gel $60 \mathrm{~F}_{254}$ (for Preparative TLC), TLC plates Silica Gel $60 \mathrm{~F}_{254}$ (for analytical TLC), and silica gel RP-18 $\mathrm{F}_{254 \mathrm{~S}}$ (for RP-TLC), were from Merck; $\mathrm{FeCl}_{3} \cdot 6 \mathrm{H}_{2} \mathrm{O}$, tetra-n-butylammonium perchlorate (TBAP) and tetramethylammonium perchlorate (TMAP) were from Fluka.

Instrumentation. ${ }^{1} H-N M R(300 \mathrm{MHz})$ and ${ }^{13} C-N M R$ spectra $(100 \mathrm{MHz})$ were recorded with a Varian Inova 400 with an ASW-SW headprobe at $30^{\circ} \mathrm{C}$. using unidimensional techniques (Dept, Apt) and bidimensional sequences (Gcosy, Ghmqc, Ghmbc, Ghsqc, where G means gradient). IR spectra were recorded with an FT-IR Bruker Vertex 70 equipped with ATR diamond cell. ESIMS spectra were recorded with a QMD 1000 Carlo Erba instrument. Cyclic voltammetric measurements were performed with a conventional three-electrode glass cell by means of a PAR-273-A potentiostat, and all solutions were prepared by using acetonitrile. As reference electrode, a silver wire immersed in a $0.1 \mathrm{M} \mathrm{AgNO}_{3}$ solution was used, linked to the main compartment of the cell by means of a Vycor plug. A platinum disk (surface area, $0.07 \mathrm{~cm}^{2}$ ) and a platinum wire were used as the working and counter electrode, respectively. The voltammograms were recorded at a concentration of the investigated compounds of $10^{-3} \mathrm{M}$, within the potential range -0.5 to $1.0 \mathrm{~V}$. As supporting electrolyte, tetra-n-butylammonium perchlorate (TBAP), tetramethylammonium perchlorate (TMAP), $\mathrm{NaClO}_{4}$ or $\mathrm{LiClO}_{4}$, were used, at a concentration of $0.1 \mathrm{M}$. EPR spectra were recorded at room temperature on a JEOL FA 100 spectrometer with $100 \mathrm{kHz}$ modulation frequency, $0.998 \mathrm{~mW}$ microwave power, $480 \mathrm{~s}$ sweep time, $0.2 \mathrm{G}$ modulation amplitude, time constant 0.3 s. Compounds 1a-1c and 4a-4c were oxidized in $\mathrm{H}_{2} \mathrm{SO}_{4}$ to give the corresponding radical-dications $\mathbf{8 H a}-\mathbf{8 H c}$ and radical-cations 10a-10c, respectively. 


\section{Synthesis of compounds $4 a-4 c$ with various oxidizing agents.}

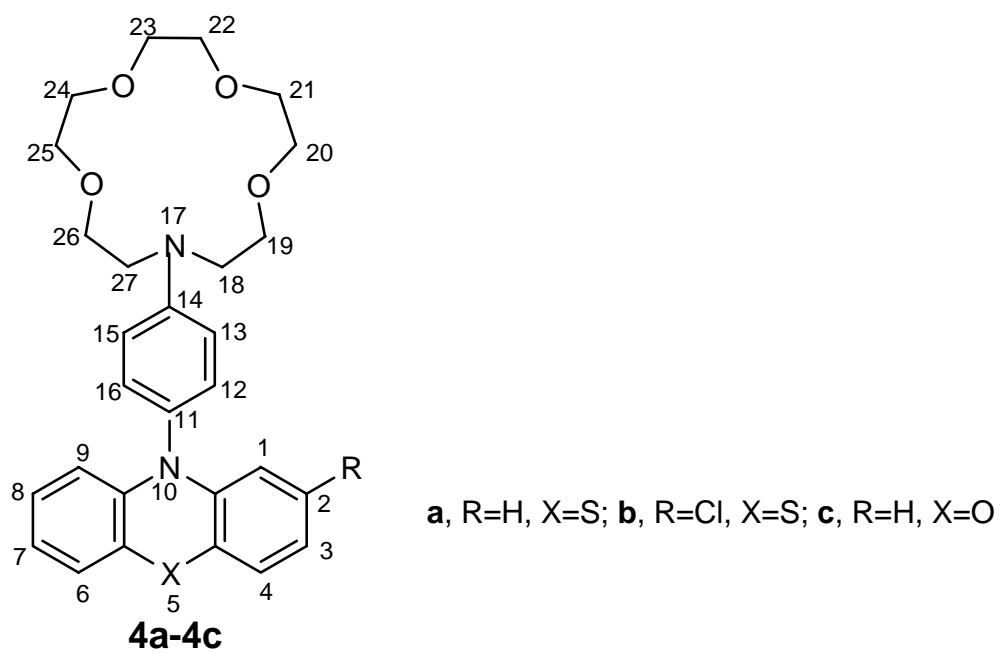

A. Oxidation with iodine. Equimolar amounts of aromatic heterocycles 1a-1c and Nphenylaza-15-crown-5 3 were dissolved in methanol $(30 \mathrm{~mL}$ for one gram of mixture) at room temperature. The pale yellow solution was treated with a solution of iodine in methanol (molar ratio $1: 1.5$ for $1: \mathrm{I}_{2}$, i. e. $40 \mathrm{~mL}$ methanol for one gram of iodine) and left for $24 \mathrm{hrs}$ with stirring at room temperature. Then distilled water (about ten times larger volume) was added to the green-brown solution, when a fine brown precipitate was formed. A solution of sodium thiosulfate was added for completely removing iodine, followed by adding ascorbic acid till the $\mathrm{pH}$ was 3.5. Solid sodium chloride was added to the grey suspension for obtaining an almost saturated solution in order to facilitate the precipitation. After keeping overnight at $5^{\circ} \mathrm{C}$, the precipitate was filtered off with suction on a G3 glass filter and washed with distilled water (from the filtrate one may isolate unreacted N-phenylaza-15-crown-5 3 with $20 \%$ yield, by extraction with methylene chloride, evaporation of the solvent, and purification by TLC). The precipitate was dissolved in methylene chloride and the extract was washed with $2 \%$ aqueous thiosulfate, and then with $2 \%$ aqueous ascorbic acid. The yellow-green organic phase was dried over sodium sulfate and then the solvent was removed under reduced pressure. The crude compounds 4a-4c were purified by preparative TLC (PLC plates Silica Gel $60 \mathrm{~F}_{254}$, dichloromethane: toluene: methanol, 5:5:0.2 v/v, four times). The extraction from silica gel was performed in a Soxhlet with dichloromethane: methanol $(9: 1 \mathrm{v} / \mathrm{v})$. Yields: $52 \%$ for $\mathbf{4 a}, 53 \%$ for $\mathbf{4 b}$ and $51 \%$ for $\mathbf{4 c}$.

B. Oxidation with anhydrous iron(III) chloride. With the same molar ratios as in the previous procedure, the methanol solution was kept for $24 \mathrm{hrs}$ at room temperature under stirring. Then distilled water (a 10-times larger volume) was added, followed by ascorbic acid to $\mathrm{pH}=3.5$ and by solid sodium chloride to reach an almost saturated solution. After keeping at $5^{\circ} \mathrm{C}$ overnight, the solution was extracted with methylene chloride, the organic phase was dried over $\mathrm{Na}_{2} \mathrm{SO}_{4}$, 
the solvent was removed and the products were isolated as indicated above. Yields: $31 \%$ for $4 \mathbf{a}$ and $30 \%$ for $\mathbf{4 c}$.

C. Oxidation with $\mathbf{C u C l}_{2} \cdot \mathbf{2} \mathbf{H}_{2} \mathrm{O}$. The procedure was similar to that outlined above under B. Yield: $50 \%$ for $\mathbf{4 a}$.

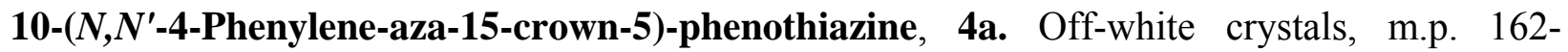
$164^{\circ} \mathrm{C}$; ESI-MS, 492, calculated for $\mathrm{C}_{28} \mathrm{H}_{32} \mathrm{~N}_{2} \mathrm{O}_{4} \mathrm{~S}$, 492; Anal.: Calcd.\%: C, 68.26; H, 6.54; N, 5.68; found\% C, 68.21; H, 6.50; N, 5.61. ${ }^{1} \mathrm{H}-\mathrm{NMR}\left(\mathrm{CDCl}_{3}, \delta \mathrm{ppm}, J \mathrm{~Hz}\right): 7.16(\mathrm{~d}, 2 \mathrm{H}, \mathrm{H}-12, \mathrm{H}-$ $16,9.0) ; 6.80(\mathrm{~d}, 2 \mathrm{H}, \mathrm{H}-13, \mathrm{H}-15,9.0) ; 6.95(\mathrm{dd}, 2 \mathrm{H}, \mathrm{H}-4, \mathrm{H}-6,1.6,7.4) ; 6.84(\mathrm{td}, 2 \mathrm{H}, \mathrm{H}-2, \mathrm{H}-8$, $7.3,1.6) ; 6.75(\mathrm{td}, 2 \mathrm{H}, \mathrm{H}-3, \mathrm{H}-7,7.4,1.2) ; 6.26(\mathrm{dd}, 2 \mathrm{H}, \mathrm{H}-1, \mathrm{H}-9,1.2,8.2) ; 3.82(\mathrm{t}, 4 \mathrm{H}, \mathrm{H}-22$, H$23,6.1) ; 3.72 \div 3.64(\mathrm{~m}, 12 \mathrm{H}, \mathrm{H}-19, \mathrm{H}-20, \mathrm{H}-21, \mathrm{H}-24, \mathrm{H}-25, \mathrm{H}-26) ; 3.64(\mathrm{t}, 4 \mathrm{H}, \mathrm{H}-18, \mathrm{H}-27$, 5.9). ${ }^{13} \mathrm{C}-\mathrm{NMR}\left(\mathrm{CDCl}_{3}, \delta \mathrm{ppm}\right): 147.21(\mathrm{C}-14) ; 145.04(\mathrm{C}-1 \mathrm{a}, \mathrm{C}-9 \mathrm{a}) ; 128.49(\mathrm{C}-11) ; 119.38(\mathrm{C}-\mathrm{C}-$ 4a, C-6a); 131.74(C-12, C-16); 112.76(C-13, C-15);126.78(C-2, C-8); 126.44(C-4, C-6); 121.94(C-3, C-7); 115.73(C-1, C-9); 71.32(C-22, C-23); 70.26(C-21, C-24); 69.95(C-20, C-25); 68.47(C-19, C-26); 52.83(C-18, C-27). FT-IR (ATR in solid, $v \mathrm{~cm}^{-1}$ ): 3055w; 2891s; 2868s; $1605 \mathrm{~m} ; 1571 \mathrm{w} ; 1514 \mathrm{vs} ; 1458 \mathrm{vs} ; 1439 \mathrm{~s} ; 1384 \mathrm{~m} ; 1348 \mathrm{~m} ; 1299 \mathrm{~s} ; 1231 \mathrm{~s} ; 1204 \mathrm{w} ; 1189 \mathrm{w} ; 1127 \mathrm{vs}$; 1109s; 1087m; 1062m; 1044m; 1007w; 977m; 944m; 755m; 739s; 618w; 549w;

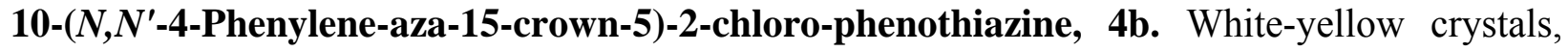
m.p. 171-172 ${ }^{\circ}$; ESI-MS, 527, calculated for $\mathrm{C}_{28} \mathrm{H}_{31} \mathrm{O}_{4} \mathrm{~N}_{2} \mathrm{SCl}$ : 527; Anal.: Calcd.\%: C, 63.80; $\mathrm{H}$, 5.92; N, 5.31; found \% C, 63.78; H, 5.89; N, 5.28; ${ }^{1} \mathrm{H}-\mathrm{NMR}\left(\mathrm{CDCl}_{3}, \delta \mathrm{ppm}, J \mathrm{~Hz}\right): 7.14(\mathrm{~d}, 2 \mathrm{H}$, $\left.\mathrm{H}-12, \mathrm{H}-16,{ }^{3} J\left(\mathrm{H}^{12(16)}-\mathrm{H}^{13(15)}\right)=9.0\right) ; 6.81\left(\mathrm{~d}, 2 \mathrm{H}, \mathrm{H}-13, \mathrm{H}-15,{ }^{3} J\left(\mathrm{H}^{13(15)}-\mathrm{H}^{12(16)}\right)=9.0\right) ; 6.94(\mathrm{dd}, 1 \mathrm{H}$, $\left.\mathrm{H}-6,{ }^{4} J\left(\mathrm{H}^{6}-\mathrm{H}^{8}\right)=1.8,{ }^{3} J\left(\mathrm{H}^{6}-\mathrm{H}^{7}\right)=7.4\right) ; 6.78\left(\mathrm{td}, 1 \mathrm{H}, \mathrm{H}-7,{ }^{3} J\left(\mathrm{H}^{7}-\mathrm{H}^{6}, \mathrm{H}^{7}-\mathrm{H}^{8}\right)=7.4,{ }^{4} J\left(\mathrm{H}^{7}-\mathrm{H}^{9}\right)=1.4\right)$; 6.82(m, 1H, H-8); 6.24(dd, $\left.1 \mathrm{H}, \mathrm{H}-9,{ }^{4} J\left(\mathrm{H}^{9}-\mathrm{H}^{7}\right)=1.4,{ }^{3} J\left(\mathrm{H}^{9}-\mathrm{H}^{8}\right)=8.2\right) ; 6.85\left(\mathrm{~d}, 1 \mathrm{H}, \mathrm{H}-4,{ }^{3} J\left(\mathrm{H}^{4}-\right.\right.$ $\left.\left.\mathrm{H}^{3}\right)=8.2\right) ; 6.73\left(\mathrm{dd}, 1 \mathrm{H}, \mathrm{H}-3,{ }^{4} J\left(\mathrm{H}^{3}-\mathrm{H}^{1}\right)=2.1,{ }^{3} J\left(\mathrm{H}^{3}-\mathrm{H}^{4}\right)=8.2\right) ; 6.26\left(\mathrm{~d}, 1 \mathrm{H}, \mathrm{H}-1,{ }^{4} J\left(\mathrm{H}^{1}-\mathrm{H}^{3}\right)=2.1\right)$; $3.83(\mathrm{t}, 4 \mathrm{H}, \mathrm{H}-22, \mathrm{H}-23,6.2) 3.72 \div 3.64(\mathrm{~m}, 16 \mathrm{H}, \mathrm{H}-18 \div \mathrm{H}-21, \mathrm{H}-24 \div \mathrm{H}-27) .{ }^{13} \mathrm{C}-\mathrm{NMR}\left(\mathrm{CDCl}_{3}, \delta\right.$ ppm): 147.58(C-14); 146.22(C-1a); 144.47(C-9a); 132.65(C-11); 127.90(C-2); 119.19(C-6a); 117.98(C-4a); 131.46(C-12, C-16); 113.01(C-13, C-15);116.12(C-9); 115.70(C-1); 121.72(C-3); 122.46(C-7); 126.98(C-6); 127.04(C-8 or C-4); 126.47(C-4 or C-8); 71.36(C-22, C-23); 70.31(C21, C-24); 70.07(C-20, C-25); 68.55(C-19, C26); 52.82(C-18, C-27).FT-IR(ATR in solid, $v \mathrm{~cm}^{-}$ $\left.{ }^{1}\right): 3069 \mathrm{w} ; 2970 \mathrm{~m} ; 2846 \mathrm{w} ; 1603 \mathrm{~m} ; 1566 \mathrm{~m} ; 1513 \mathrm{~s} ; 1483 \mathrm{w} ; 1458 \mathrm{vs} ; 1441 \mathrm{~m} ; 1389 \mathrm{~s} ; 1361 \mathrm{~m}$; 1349m; 1291s; 1251m; 1138s; 1109vs; 1043m; 992m; 956m; 927m; 823m; 743s; 561w.

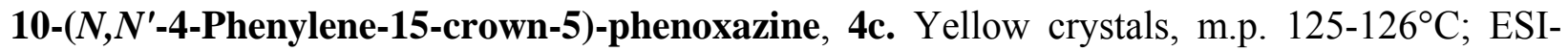
MS, 476, calculated for $\mathrm{C}_{28} \mathrm{H}_{32} \mathrm{O}_{5} \mathrm{~N}_{2}$ : 476; Anal.: Calcd.\% C, 70.56; H, 6.76; N, 5. 87; found \% C, 70.52; H, 6.74; N, 5.80; ${ }^{1} \mathrm{H}-\mathrm{NMR}\left(\mathrm{CDCl}_{3}, \delta \mathrm{ppm}, J \mathrm{~Hz}\right): 7.10(\mathrm{~d}, \mathrm{H}-12, \mathrm{H}-16,8.6)$; 6.78(d, H-

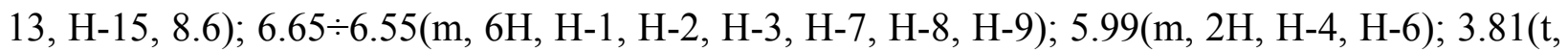
$4 \mathrm{H}, \mathrm{H}-22, \mathrm{H}-23,6.0) ; 3.78 \div 3.65(\mathrm{~m}, 12 \mathrm{H}, \mathrm{H}-19, \mathrm{H}-20, \mathrm{H}-21, \mathrm{H}-24, \mathrm{H}-25, \mathrm{H}-26) ; 3.64(\mathrm{t}, 4 \mathrm{H}, \mathrm{H}-$ 18, H-27, 5.9). ${ }^{13} \mathrm{C}-\mathrm{NMR}\left(\mathrm{CDCl}_{3}, \delta \mathrm{ppm}\right): 147.35(\mathrm{C}-14) ; 144.02(\mathrm{C}-4 \mathrm{a}, \mathrm{C}-6 \mathrm{a}) ; 135.18(\mathrm{C}-1 \mathrm{a}, \mathrm{C}-$ 9a); 126.48(C-11);131.22(C-12, C-16); 123.18(C-3, C-7); 120.74(C-2, C-8); 115.10(C-1, C-9); 113.32(C-4, C-6); 113.15(C-13, C-15);71.31(C-22, C-23); 70.26(C-21, C-24); 69.97(C-20, C25); 68.48(C-19, C-26); 52.82(C-18, C-27). FT-IR (ATR in solid, $v \mathrm{~cm}^{-1}$ ): 3057w; 2935w; 
2891m; 2871m; 1624w; 1604w; 1590w; 1516s; 1479vs; 1387w; 1350m; 1323s; 1289m; 1265s; $1207 \mathrm{w} ; 1129 \mathrm{~m} ; 1111 \mathrm{~s} ; 1091 \mathrm{~m} ; 1065 \mathrm{w} ; 980 \mathrm{w} ; 945 \mathrm{w} ; 861 \mathrm{w} ; 754 \mathrm{~m} ; 740 \mathrm{~m} ; 584 \mathrm{w}$;

\section{Synthesis of compound 7}

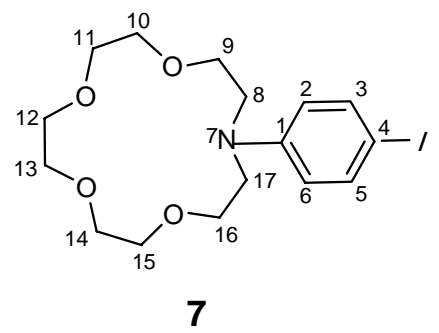

A $10 \% \mathrm{w} / \mathrm{w}$ solution of $N$-phenylaza-15-crown-5 3 in methanol was treated with a solution of iodine in methanol (40 mL for one gram of $\mathrm{I}_{2}$, molar ratio 1:1.5 for $3: \mathrm{I}_{2}$ ). The brown solution was stirred at room temperature for $24 \mathrm{hrs}$. A tenfold larger volume of distilled water was added, when a fine brown precipitate separated. Then solid sodium thiosulfate was added under stirring till the solution became colorless. After bringing the $\mathrm{pH}$ to 3.5 with solid ascorbic acid, the suspension was kept overnight at $5^{\circ} \mathrm{C}$. Solid sodium chloride was added to saturation, and the solution was extracted with methylene chloride. After drying over $\mathrm{Na}_{2} \mathrm{SO}_{4}$, the solvent was removed under reduced pressure. Purification was carried out by preparative TLC as outlined above. Yield 74\%.

$N$-(4-Iodophenyl)-aza-15-crown-5, 7. Waxy product. ESI-MS, 421, calculated for $\mathrm{C}_{16} \mathrm{H}_{24} \mathrm{O}_{4} \mathrm{NI}$ : 421; Anal.: Calcd.\% C, 45.61; H, 5.74; N, 3.32; found\% C, 45.59; H, 5.71; N, 3.30; ${ }^{1} \mathrm{H}-\mathrm{NMR}$ $\left(\mathrm{CDCl}_{3}, \delta \mathrm{ppm}, J \mathrm{~Hz}\right): 7.43(\mathrm{~d}, 2 \mathrm{H}, \mathrm{H}-3, \mathrm{H}-5,9.1) ; 6.44(\mathrm{~d}, 2 \mathrm{H}, \mathrm{H}-2, \mathrm{H}-6,9.1) ; 3.72(\mathrm{t}, 4 \mathrm{H}, \mathrm{H}-12$, $\mathrm{H}-13,6.2) ; 3.68 \div 3.63(\mathrm{~m}, 12 \mathrm{H}, \mathrm{H}-9 \div \mathrm{H}-11$, H-14 $\div \mathrm{H}-16) ; 3.55(\mathrm{t}, 4 \mathrm{H}, \mathrm{H}-8, \mathrm{H}-17,6.2) ;{ }^{13} \mathrm{C}-\mathrm{NMR}$ $\left(\mathrm{CDCl}_{3}, \delta \mathrm{ppm}\right): 147.09(\mathrm{C}-1) ; 137.71(\mathrm{C}-3, \mathrm{C}-7) ; 113.81(\mathrm{C}-2, \mathrm{C}-6) ; 76.30(\mathrm{C}-4) ; 71.31(\mathrm{C}-12$, C13); 70.18(C-11, C-14); 70.09(C-10, C-15); 68.23(C-9, C-16); 52.50(C-8, C-9).

Monitoring the reaction between 1a and 3 by cyclic voltammetry. An equimolar mixture of compounds 1a and $\mathbf{3}$ in acetonitrile in the presence of TBAP was monitored analytically by cyclic voltammetry following the redox processes (Figure 1). Then, on adding a tenfold volume of distilled water to the solution, the milky liquid phase was extracted $\mathrm{L} / \mathrm{L}$ with methylene chloride. The lower phase was separated, dried over $\mathrm{Na}_{2} \mathrm{SO}_{4}$, and concentrated under reduced pressure to about $0.1 \mathrm{~mL}$. The TLC analysis confirmed the mechanism described by Scheme 2 by identifying the starting materials $\mathbf{1 a}$, $\mathbf{3}$, of the reaction product $\mathbf{4 a}$ (traces), and of traces of dimers $5 \mathbf{a}, \mathbf{6 a}$ resulting from the free radical $\mathbf{2 a}$.

TLC behavior. TLC analyses (Table 8) were employed for identification, purification, and purity determination. For the dimers $\mathbf{5 a}-\mathbf{5 c}$ and $\mathbf{6 a - 6} \mathbf{c}^{22,28}$ the "fingerprint" test had used as standard the solution obtained by treating compounds 1a-1c with solid $\mathrm{PbO}_{2}$ in methylene 
chloride; this solution contained unreacted compounds $\mathbf{1 a}-\mathbf{1 c}$ and the dimers $(\mathbf{5 a}-\mathbf{5 c}+\mathbf{6 a - 6})$. On analytical silica gel $60 \mathrm{~F}_{254}$ (Merck) plates the three mobile phases (A-C) allowed the identification of unreacted starting materials (1a-1c), reaction products $\mathbf{4 a - 4 c}$, dimeric sideproducts 5a-5c, 6a-6c, and compound 7. Detection of spots employed UV light (254 nm for non-fluorescent background, or $366 \mathrm{~nm}$ for fluorescent background) as well as iodine vapor yielding various colors indicated in Table 8.

Table 8. TLC data of compounds 1, 3-7 on silica gel analytical plates

\begin{tabular}{ccccccc}
\hline & \multicolumn{2}{c}{$R_{f}$} & \multicolumn{3}{c}{ Detection } \\
\cline { 2 - 7 } Comp. & $\mathrm{A}$ & $\mathrm{B}$ & $\mathrm{C}$ & $\mathrm{UV}$ & $\mathrm{UV}$ & Iodine vapor \\
\hline $\mathbf{1 a}$ & 0.625 & 0.964 & & Grey & $\mathrm{Fl}^{\mathrm{b}}$ & Green \\
$\mathbf{1 b}$ & 0.750 & 0.964 & & Grey & $\mathrm{Fl}^{\mathrm{b}}$ & Green \\
$\mathbf{1 c}$ & 0.650 & 0.964 & & Grey & $\mathrm{Fl}^{\mathrm{b}}$ & Blue \\
$\mathbf{3}$ & 0 & 0.317 & 0.285 & Grey & & Yellow \\
$\mathbf{4 a}$ & 0 & 0.329 & & Grey & $\mathrm{Fl}^{\mathrm{b}}$ & Purple-green \\
$\mathbf{4 b}$ & 0 & 0.353 & & Grey & $\mathrm{Fl}^{\mathrm{b}}$ & Green \\
$\mathbf{4} \mathbf{c}$ & 0 & 0.341 & & Grey & $\mathrm{Fl}^{\mathrm{b}}$ & Orange \\
$\mathbf{5 a}$ & 0.525 & 0.964 & & Grey & $\mathrm{Fl}^{\mathrm{b}}$ & Green \\
$\mathbf{6 a}$ & 0.337 & 0.964 & & Grey & $\mathrm{Fl}^{\mathrm{b}}$ & Green \\
$\mathbf{5} \mathbf{b}^{\mathrm{a}}$ & 0.675 & 0.964 & & Grey & $\mathrm{Fl}^{\mathrm{b}}$ & Green \\
$\mathbf{6 b}^{\mathrm{a}}$ & 0.587 & 0.964 & & Grey & $\mathrm{Fl}^{\mathrm{b}}$ & Green \\
$\mathbf{5} \mathbf{c}^{\mathrm{a}}$ & 0.550 & 0.964 & & Grey & $\mathrm{Fl}^{\mathrm{b}}$ & Green-blue \\
$\mathbf{6 c}^{\mathrm{a}}$ & 0.475 & 0.964 & & Grey & $\mathrm{Fl}^{\mathrm{b}}$ & Green-blue \\
$\mathbf{7}$ & 0 & 0.470 & 0.380 & Grey & & Yellow-brown \\
\hline
\end{tabular}

(A) toluene: $n$-hexane=6:4 (v/v) twice; (B) $\mathrm{CH}_{2} \mathrm{H}_{2}$ :toluene:MeOH=5:5:0.2 (v/v) four times; (C) $\mathrm{CHCl}_{3}: \mathrm{MeOH}=10: 0.2(\mathrm{v} / \mathrm{v})$; ${ }^{\mathrm{a}}$ order of migration $\left(R_{f}\right)$ by analogy with literature data; ${ }^{22,27 \mathrm{~b}} \mathrm{Fl}=$ weakly fluorescent.

\section{References}

1. Wurster, C. Ber. dtsch. chem. Ges. 1879, 12, 522.

2. The Merck Index, $14^{\text {th }}$ Edition; Merck \& Co., Inc. Whitehouse Station, N.J., USA, 2006; pp. 25, 157, 261, 472, 1045, 1587 and references cited therein.

3. Forrester, A. R.; Hay, J. M.; Thomson, R. H. Organic Chemistry of Stable Free Radicals; Academic Press, London, 1968; pp. 125, 127, 254 and references cited therein.

4. http://www.chemie.uni-regensburg.de/Organische_Chemie/Didaktik/Keusch/D-Wurster-e.htm.

5. Pearson, A. J.; Hwang, J. J. Tetrahedron Lett. 2001, 42, 3533. 
6. Pearson, A. J.; Hwang, J. J.; Ignatov, M. E. Tetrahedron Lett. 2001, 42, 3537.

7. Pearson, A. J.; Hwang, J. J. Tetrahedron Lett. 2001, 42, 3541.

8. Sibert, J. W.; Forshee, P. B.; Hundt, G. R.; Sargent, A. L.; Bott, S. G.; Lynch, V. Inorg. Chem. 2007, 46, 10913.

9. De Backer, M.; Hureau, M.; Depriester, M.; Deletoille, A.; Sargent, A. L.; Forshee, P. B.; Sibert, J. W. J. Electroanal. Chem. 2008, 612, 97.

10. Al-Amir, S. M. S.; Ashworth, D. C.; Narayanaswamy, R.; Moss, R. E. Talanta 1989, 36, 645.

11. Zeng, W.; Du, Y.; Li, H.; Lu, X.; Qin, S. Org. Prep. Proc. Internat. 2003, 35, 228.

12. Ataman, D.; Akkaya, E. U. Tetrahedron Lett. 2002, 43, 3981.

13. Boila-Gokel, A.; Fabian, W. M. F.; Junek, H. Liebigs Ann. Chem. 1996, 397.

14. Fery-Forgues, S.; Bourson, J.; Dallery, L.; Valeur, B. New J. Chem. 1990, 14, 617.

15. Dix, J. P.; Vögtle, F. Chem. Ber. 1981, 114, 638.

16. Dix, J. P.; Vögtle, F. Chem. Ber. 1980, 113, 457.

17. Dryhurst, G.; Kadish, K. M.; Scheller, F.; Renneberg, R. Biological Electrochemistry; Academic Press, Inc., New York, 1982; Vol. 1, p. 180 and references cited therein.

18. Bodea, C.; Silberg, I. Adv. Heterocyclic Chem.; Academic Press, New York, 1968; Vol. 9, pp. 321, 331, 355, 378 and references cited therein.

19. Ionescu, M.; Mantsch, H. Adv. Heterocyclic Chem.; Academic Press, New York, 1967; Vol. 8, pp. 83, 91, 95-97 and references cited therein.

20. Haugland, R. P., The Handbook: A Guide to Fluorescent Probes and Labeling Technologies, $10^{\text {th }}$ Edn.; Molecular Probes, Inc., The Netherlands, 2005; pp. 521, 535, 711 and references cited therein.

21. Tsujino, Y. Tetrahedron Lett. 1968, 21, 2545.

22. Tsujino, Y. Tetrahedron Lett. 1968, 38, 4111.

23. Wanzlick, H. W.; Horchler, M. L.; Mohrmann, S.; Gritzky, R.; Heidepriem, H.; Pankow, B. Angew. Chem. Internat. Edit. 1964, 3, 401.

24. Daneke, J.; Wanzlick, H.-W. Liebigs Ann. Chem. 1970, 740, 52.

25. Raileanu, M.; Radulian, I. Rev. Roum. Chim. 1973, 18, 1005.

26. Jacksen, C.; Patel, N. K. D. Tetrahedron Lett. 1967, 2255.

27. Constantinescu, T.; Enache, S.; Vasiliev, R. Rev. Roum. Chim. 1978, 23, 967.

28. Tang, W.-S.; Lu, X.-X.; Wong, M.-C.; Yam, V. W.-W. J. Mater. Chem. 2005, 15, 2714.

29. Tiecco, M. Pure \& Appl. Chem. 1981, 53, 239.

30. Bourson, J.; Pouget, J.; Valeur, B. J. Phys. Chem. 1993, 97, 4552.

31. Gilbert, B. C.; Hanson, P.; Norman, R. O. C.; Sutcliffe, B. T. Chem. Commun. 1966, 161.

32. Chapman, D. M.; Buchanan III, A. C.; Smith, G. P.; Mamantov, G. J. Am. Chem. Soc. 1986 , $108,654$.

33. Tuck, L. D.; Schieser, D. W. J. Phys. Chem. 1962, 937.

34. Shine, H. J.; Mach, E. E. J. Org. Chem. 1965, 30, 2130.

35. Kemp, T. J.; Moore, P.; Quick, G. R. J. Chem. Soc., Perkin Trans. 1 1980, 2, 291.

36. Chiu, M. F.; Gilbert, B. C.; Hanson, P. J. Chem. Soc. 1977, 99, 6506. 
37. Sullivan, P. D.; Bolton, J. R. J. Magn. Reson. 1969, 1, 356.

38. Hansch, C.; Leo, A. Substituent Constants for Correlation Analysis in Chemistry and Biology; Wiley, New York, 1979.

39. Kossoy, A. D.; Risley, D. S.; Kleyle, R. M.; Nurok, D. Anal. Chem. 1992, 64, 1345.

40. Soczewinski, E. Anal. Chem. 1969, 41, 179.

41. Baratoiu, R. D.; Mutihac, L.; Caproiu, M. T.; Draghici, C.; Dumitrascu, F.; Socoteanu, R.; Beteringhe, A.; Maganu, M.; Covaci, I. C.; Bem, M.; Constantinescu, T.; Balaban, A. T. Arkivoc 2008, (xi), 307.

42. Bem, M.; Badea, F.; Draghici, C.; Caproiu, M. T.; Vasilescu, M.; Voicescu, M.; Pencu, G.; Beteringhe, A.; Maganu, M.; Covaci, I. C.; Constantinescu, T.; Balaban, A. T. Arkivoc 2008, (ii), 218.

43. Radutiu, A. C.; Baciu, I.; Caproiu, M. T.; Draghici, C.; Nicolae, A.; Constantinescu, T.; Balaban, A. T. Arkivoc 2007, (xiii), 8.

44. ACD/ChemSketch (Freeware Version), www.acdlabs.com, 2009. 